\title{
Music to labour to
}

\author{
RICHARD SMITH
}

The woman on the Clapham omnibus, who these days, of course, will be seen more often on her Raleigh Roadster or on exceptionally inclement days in her canary yellow Deux Chevaux, would no more consider giving birth without music than she would eating at Macdonald's. One of these Clapham women, though of a different ilk, is Lin, my wife. We obviously haven't lived long enough in Clapham because what music we would choose for labour wasn't the first question to come into our minds when pregnancy came upon us. Later two happenings alerted us to the fact that we must give as much attention to music as to regular breathing and relaxing.

The first was the labour of a friend in a London teaching hospital. The professor turned up at 6 am to deliver her (she was a psychiatrist not a private patient) and brought his own music with him. He opted for Mahler's first symphony-The Titan. Now that is a piece of music we both enjoy-indeed, associate with the early days of our relationship-but the thought of giving birth to the funeral march that is Frere facques transposed into the minor key or those mad waltzes was more than either of us could contemplate.

The second occasion was the fathers' class at St Thomas's when after a tedious film and an interminable talk the nurse gave us some practical advice: "Bring your own music because the tapes we have here are not awfully good." If we didn't bring our own, Lin might have to labour to Mantovani or Abba. We began to concentrate on this serious problem.

We began in an abstract way by considering the characteristics of the perfect labouring music. It would, we imagined, be lyrical and calming, with a regular pulse and without too many violent changes of tempo, dynamics, or key. But we couldn't in this way summon a piece to mind, and so we resorted to the exclusion method. We began to sift through our large and broad record collection.

\section{Resorting to exclusion}

Two categories of music went by the board almost immediately -folk music and opera. Opera is just too passionate, and folk music we have grown out of. Next we dispensed with modern music of the more strident kind and big band music. Stockhausen, Berio, Albert Ayler, Anthony Braxton, and the Art Ensemble of Chicago, though great favourites of mine, seemed too wild. Shostakovich, Bartok, Gershwin, and the Modern Jazz Quartet in their gentler moments were all, however, still in with a chance. The big bands of Count Basie, Artie Shaw, Benny Goodman, and Woody Herman were all out too on the grounds that they were "too busy." (Imagine entering the second stage of labour to the frenetic and famous Gene Krupa drum solo or the Carnegie Hall version of Sing, Sing, Sing.) Duke Ellington's music remained a possibility.

We also ruled out most rock and pop music on grounds of stridency, although the Rolling Stones' music does seem to have potent labour inducing properties : five women gave birth during their famous Altamont concert-but then five people died as well. Heavy metal we've never liked, but reggae and two tone seemed possibilities as did the more lyrical of the older bands-the Beatles, the Beach Boys, and the Loving Spoonful, for instance.

British Medical Journal, London WC1H 9JR

RICHARD SMITH, MB, BS, assistant editor
We were making slow progress, but when we thought more closely about the criteria on which we were excluding music we could see that we were moving towards intimate music. The symphonies and concertos of Beethoven, Brahms, Tchaikovsky, Sibelius, and Mahler all seemed far too grand, but we didn't immediately exclude those of Mozart, Schubert, and Haydn. Indeed, the further back we went in musical history the more appropriate sounded much of the music. The orchestral music of Bach and Vivaldi seemed stronger possibilities than that of Mozart, whereas Paganini and Liszt were never in the running. Going further back still Gregorian chants seemed a very attractive possibility, except that they were maybe too mournful. But Gregorian chants sung by the Benedictine monks of the Abbey of St Maurice and St Maur, Clervaux, did end up as finalists along with the Brandenberg concertos and Vivaldi's Four Seasons.

Not all modern orchestral music was immediately excluded. Vaughan Williams's Fantasy on a Theme by Thomas Tallis, Gershwin's Rhapsody in Blue, Shostakovich's second piano concerto, and Rodriguez's Concerto de Aranjuez were all carefully considered, but none were finalists. (Interestingly, we also thought about Miles Davis's haunting trumpet variations of the Rodriguez concerto; Rodriguez himself hated it, but we like it very much.)

If intimacy was an important characteristic then chamber music, we thought, would have much to offer. The string quartets of Mozart, Haydn, and Beethoven all beckoned as did those of Bartok, Shostakovich, Ravel, and Debussy. But it was Schubert who sounded most attractive. The Trout was a finalist as was the Schubert quintet, which was particularly appropriate, for the child about to be born might well have been conceived to the slow movement of that quintet. We have a big collection of chamber clarinet music, but that was all dismissed immediately on the grounds that it might remind Lin of my dreadful clarinet playing.

Schubert had another finalist when we came to consider piano music-Arturo Benedetti Michelangeli playing his sonata in A minor. Chopin's preludes were also finalists. Most of our Beethoven again seemed too tempestuous, but his second sonata played by Barenboim was a finalist. Some of Debussy's piano music came close, but the moods of the music change too fast.

\section{Problems with jazz}

Up until now we had been largely in agreement, but the problems began when we came to consider jazz. More than half of our collection is jazz, and much of it Lin dislikes: she has been overexposed to jazz. If I were labouring or, indeed, going through any epic moment in my life then I would look for accompaniment to John Coltrane, Miles Davis, Charlie Parker, Eric Dolphy, Thelonius Monk, Rahsaan Roland Kirk, Cannonball Adderly, Tubby Hayes, Tony Coe, Stan Getz, Charlie Mingus, Paul Desmond, Gato Barbieri, John Surman, or Lester Young. (Maybe an endless recitation of these wonderful names would be accompaniment enough.) But most of these were non-starters to Lin, and as she would be a costar while I had only a minor supporting role in the approaching drama I had to submit. Some jazz she did, however, consider.

One jazz record that she has always enjoyed is Gato Barbieri's Under Fire, which is a musical journey through Brazil, but she eventually decided that such steamy, unsettled music would be torture in the heat of labour. Much cooler are the Modern Jazz 
Quartet and John Coltrane's record The Gentle Side of Coltrane: the marvellous freshness of Coltrane's After the Rain was particularly attractive. Both were among the finalists, along with Keith Jarrett's Koln Concert-four prolomged, ecstatic, lyrical piano improvisations. We had seen Jarrett play at the Royal Festival Hall, and he seemed himself to be going into labour at times as he played. Whether his antics and his music are bogus or sincere I've still not decided, but we do enjoy his music. We often eat to it, and music for eating and labouring can't be that different.

The other jazz that Lin considered was all vocal: Ella Fitzgerald singing Gershwin; Astrud Gilberto singing with Stan Get\%, "It might as well be spring"; and Nat King Cole singing with George Shearing. While thinking about songs we also considered Canteloube's Songs of the Auvergne and Berlioz's Les Nuits d'Été, but we eventually decided that words got in the way. For the same reason and because of their exuberance we rejected two of Lin's favourite records, songs from Guys and Dolls and Cabaret: imagine experiencing that divine moment when a new life begins to the strains of "Sit Down, You're Rocking the Boat." It couldn't be.

This process of exclusion took us months, and we were becoming heartily sick of it: silence, or the ticking of all those machines, didn't seem such dreadful options. At least then you wouldn't have to change the tape. God, or whatever it is that starts labour, must have thought so too because labour started before we had made our final decision. We rattled off in the ambulance musicless, and all that St Thomas's could offer was Cliff Richard at the wrong speed. Freddie P Smith's arrival was celebrated only with shrieks, pants, and grunts; and none of us missed the music.

\title{
In praise of the Basuto pony
}

\author{
SAM RAMSAY SMITH
}

It gets cold up in the mountains of Lesotho in winter and yesterday, although it is spring, was no exception. Even though the early morning sun was shining, it was still very cold, but it did not seem to bother me for I was about to embark on an African adventure and was full of anticipation and a certain degree of excitement. I was to go to a village so remote and small that I could barely find it on the large scale map I had of the district-all I knew was that to get there meant a good half a day's ride on horseback over some difficult mountain terrain.

I had been asked as district medical officer to accompany some of the local police to the village of Qabane (no $U$, and pronounced Khabané) some way beyond the north bank of the Orange River and to the north of a town called Sekakes, where we had one of our peripheral health centres. Apparently, I was required to perform an exhumation on a member of the chief's family who had died in March this year and was now known to have been murdered.

\section{A bag of biltong}

At this time of year both my wife Marta and I are extremely busy-much more so than usual since we are finalising the arrangements for transferring our patients from the old hospital to the new one, recently completed and now my responsibility to start running and then to manage for a further two years. Thus we received the request from Lieutenant Colonel Chaka of the Lesotho Mounted Police with mixed feelings; nevertheless, it was in response to this request that I found myself on this cold morning filling my saddle bags at 630 am with a varied assortment of articles from a mortuary kit to a bag of biltong-the dried, preserved meat of various animals from domestic beef to wild antelope, but it is also made from ostrich flesh. I have recently begun to make my own, because of its high price in the shops, and this was an excellent opportunity to try out my first, home made batch, since biltong is extremely nutritious, light to carry, and well preserved, and is the ideal food for this sort of trip.

Just after 700 am I am on my way to Sekakes, the village where I shall leave my Toyota Landcruiser and take to horseback. The early morning sun is magnificent, and the peach blossom is ubiquitous-pink islands on the barren rocks of the mountains competing with the mimosa for a share of the bright colour on the hill sides. Smoke is curling in the early morning light from the roofs of many of the village huts that I pass-trees are scarce in Lesotho, and the primary source of fuel is compressed cow and goat dung-but it is like peat in quality and burns well for a long time if well made. There is little traffic on these twisted mountain roads at the best of times, and I do not pass a single vehicle on my way to Sekakes, a drive of just over 90 minutes.

\section{Black Beauty}

By 900 am I am mounted on a fine, black horse supplied by the police. I am sitting on the saddle I gave Marta as a birthday present-supposed to be very comfortable. I sling my saddle bags over the back of the saddle and we are off; my escort comprises a sergeant of the criminal investigation department and a detective trooper, both heavily armed. They tell me that things can be "awkward" in the mountains, which is why they go armed on these trips and, furthermore, most of the time they went "footing it" since it seems that the mountain people can recognise a police horse from afar and can thus take evasive action at an early stage if deemed necessary.

It takes us an hour to make the long descent to the place where we shall cross the Orange River, but passing down the narrow, winding bridle path we meet many people. There are small groups of men on their ponies, women carrying all manner of goods on their heads, from their own shoes as they cross the river to such interesting items as two chickens, a six can pack of beer, to a door complete in its frame, and then the mules-long lines of them winding slowly up the tortuous track carrying great sacks of maize and barrels of joala, the locally produced foment from maize.

I have travelled to my work in Africa by a variety of meanscanoes in Cameroun, aeroplanes in Zaire, and the footplate of a steam train in Kenya-but the mode of transport I was forced to adopt today is possibly the most pleasant of all. I have never spent more than two hours on horseback continuously before, 